REVIEW

\title{
Use of localised gene transfer to develop new treatment strategies for the salivary component of Sjögren's syndrome
}

\author{
M R Kok, B J Baum, P P Tak, S R Pillemer
}

Ann Rheum Dis 2003;62:1038-1046

Effective treatment for Sjögren's syndrome (SS) might be developed locally by introducing genes encoding cytokines, which are potentially anti-inflammatory, or by introducing a cDNA encoding a soluble form of a key cytokine receptor, which can act as an antagonist and decrease the availability of certain cytokines, such as soluble tumour necrosis factor $\alpha$ receptors. Currently, the preferred choice of viral vector for immunomodulatory gene transfer is recombinant adeno-associated virus. The use of gene transfer to help determine the pathophysiology and to alter the course of the SS-like disease in the NOD mouse model can ultimately lead to the development of new treatments for managing the salivary component in patients with SS.

See end of article for authors' affiliations

Correspondence to: Dr M R Kok, Meibergdreef 9 , Room F4-218, 1105

A'Z, Amsterdam, The Netherlands;

m.r.kok@amc.uva.nl

Accepted 1 May 2003
S jögren's syndrome (SS) is an autoimmune disorder characterised by decreased lachrymal and salivary gland function, which can also affect multiple organs, including kidney and lung. ${ }^{1}$ The principal lesion in SS is lymphocytic infiltration in target tissues. ${ }^{2}$ Lachrymal and salivary gland inflammation is most prominent and associated with decreased production of tears (associated with keratoconjunctivitis sicca) and saliva (resulting in xerostomia). The reported prevalence of primary SS varies from $0.05 \%$ to $4.8 \%$ of the population and the reported incidence of cases diagnosed by a doctor is 4 per 100000 population a year. ${ }^{3}$ The prevalence and incidence reported are influenced by subject selection and the classification criteria applied. Women are nine times more likely to be affected than men and the symptoms appear to increase with age. ${ }^{13}$

Early events in human SS are difficult to relatively late in the disease. This, and the inability to perform unlimited serial salivary gland biopsies in patients with SS, for practical and ethical reasons, underlines the importance of having representative animal models for the disease.

Treatment of SS currently involves the alleviation of the exocrine and systemic manifestations. In addition to local treatment using artificial tears and oral preparations, muscarinic agents, such as cevimeline (M3 muscarinic receptorspecific agonist) and pilocarpine (non-specific muscarinic agonist) are used to stimulate secretions. ${ }^{5}$ For systemic intervention in the disease, recognise because symptoms usually manifest hydroxychloroquine, steroids, and other immunomodulatory agents are sometimes used. ${ }^{67}$ The current array of treatments is unsatisfactory for most patients, so the development of new treatment strategies for SS is necessary. Recently, several "biological therapies", employing recombinant immunomodulatory proteins, have been shown to be useful in other autoimmune disorders. ${ }^{8}$ Although the potential use of these agents in SS has yet to be unequivocally demonstrated, immune modulation using recombinant proteins, such as soluble tumour necrosis factor $\alpha(\mathrm{TNF} \alpha)$ inhibitors, is inconvenient for patients to administer. Furthermore, they cannot be targeted to the active site of disease and, after injection tend to be cleared rapidly from the system. ${ }^{8}$ Modulation of salivary cellular functions by gene transfer into these target tissues may provide a number of therapeutic options for the management of SS. ${ }^{9}$ Because the exocrine manifestations of SS rather than the systemic features are prominent, we will emphasise here the role of salivary tissues as localised targets for immune modulation through gene transfer, primarily using recombinant adeno-associated viruses (AAVs). We will discuss how and where to deliver transgenes, the safety of gene transfer for patients with SS, potential candidate genes to consider for local intervention in SS, and the animal models that can be used to investigate the effects of a gene transfer intervention. We refer to other review articles for a comprehensive general review of gene transfer vectors ${ }^{10}{ }^{11}$ or of the immunopathological mechanisms possibly operative in SS. ${ }^{12}{ }^{13}$

\section{GENE TRANSFER}

Gene transfer refers to a technology that delivers a segment of DNA into target cells or tissues. Gene transfer can involve the direct introduction of a gene or cDNA (that is, the transgene) into diseased cells to restore normal function. Alternatively, the target cells can be normal, but are used to produce a functional, secreted

\footnotetext{
Abbreviations: AAV, adeno-associated virus; BLyS, B lymphocyte stimulation; ICAM, intercellular adhesion molecule; IFN $\gamma$, interferon $\gamma$; IL, interleukin; LFA, leucocyte function associated antigen; MHC, major histocompatibility complex; NOD, non-obese diabetic; RA, rheumatoid arthritis; rAAV, recombinant adenoassociated virus; RT-PCR, reverse transcriptionpolymerase chain reaction; SCID, severe combined immunodeficiency; SS, Sjögren's syndrome; TNF $\alpha$, tumour necrosis factor $\alpha$; VCAM, vascular cell adhesion molecule
} 
protein to correct malfunctions in other cells and tissues. Generally, there are two ways to transfer genes, using viruses or using non-viral methods. ${ }^{9}{ }^{10}$ For clinically successful gene transfer it is essential to have a good understanding of the normal physiology of the target cell, and the clinical features, immunological, molecular and cellular pathobiology of the disease. For salivary glands, as well as other tissues, an effective gene delivery vector requires several components. The vector must appropriately package the gene providing protection from the extracellular environment. It must allow binding and uptake by the target cells and should facilitate delivery of the gene to the nucleus. Ideally, for a rheumatic disease, the vector carrying the gene of interest should provide stable expression-for example, by integrating the transgene into the host genome. Also it is desirable to provide tissue-specific transcriptional control-for example, using cell-specific promoters and/or other regulatory elements, to prevent unwanted transgene expression elsewhere. ${ }^{14}$ For persistence of gene expression, the vector and gene product should not be immunogenic to avoid a potent immune response and destruction of the transduced cell. ${ }^{15}$

\section{Methods of gene delivery in salivary glands Non-viral vectors}

Naked DNA plasmids, either alone or complexed with various cationic molecules, can be used to deliver genes. In vitro, generally good transfection, with many cell types can be achieved. Complexing plasmid DNA with cationic formulations enhances cellular entry, the transfer of a transgene by a non-viral vector, and expression of that transgene in the target cell. Non-viral vectors, in general, are significantly less immunogenic than viral vectors, ${ }^{16}$ but in vivo, the efficiency of gene transfer of non-viral vectors is low, making them less favourable for in vivo gene transfer at present (table 1).

\section{Viral vectors}

Viruses have evolved efficient ways to enter into host cells and replicate. This ability makes them useful as gene transfer vectors. Currently, viral vectors provide the most efficient method of performing clinically useful gene transfer. The vast majority of gene transfer studies in salivary glands have used adenoviruses, and more recently recombinant adenoassociated viruses (rAAVs). Occasionally other viral vectors have been employed in salivary glands. For example, there are single reports of recombinant vaccinia, herpes, and lentiviruses being used. ${ }^{17}$ Such infrequently used vectors will not be discussed further here.

\section{"Viruses are efficient gene transfer vectors"}

Ideally, all recombinant viral vectors should be constructed as being non-competent for replication, and deleted of viral structural genes, which may be cytotoxic or immunogenic. Viral vectors should also retain full infectious ability and mediate the required level of transgene expression in the target cells. Retroviral vectors can integrate into the host chromosome. However, transduction by most retroviral vectors (not lentiviral vectors, however) requires cell division, and at present they also cannot be grown in high titres. Consequently, most retroviral vectors can only be used ex vivo, ${ }^{18}$ an impractical feature for use with salivary glands.

Adenoviral vectors can efficiently infect dividing and nondividing cells, including highly differentiated tissues such as salivary glands. They can be easily grown in large amounts and have efficient transduction rates in vivo. For these reasons, adenoviral vectors have commonly been used in salivary gland gene transfer studies. However, these vectors do not mediate transgene integration into the host cell genome. The absence of genomic integration results in transient expression of the transgene. In addition, adenoviral vectors elicit a potent host immune response in the salivary gland, making them for many clinical applications less than ideal vectors. ${ }^{15} 19$

Recently, many laboratories have explored the possible use of rAAVs (serotype 2) for in vivo gene transfer. AAV is a small single stranded DNA parvovirus. Wild-type AAV has the ability to integrate into a specific non-mutagenic site on chromosome 19. However, although rAAVs do not retain this ability for site-specific integration, they do appear to provide stable expression through a long term extrachromosomal presence. rAAVs have the potential for transducing a wide range of host cells and are considered to be non-pathogenic. ${ }^{20}$ Importantly, rAAV serotype 2 transduces the ductal cells in salivary glands. ${ }^{21} 22$

\section{Systemic versus local salivary gland delivery}

Gene delivery can be performed systemically or locally. When a transgene is delivered in patients with SS by a route that is remote from the active disease site, such as into muscle or intravenously, more systemic sequelae, both related to the vector and to the transgene product, can be expected. Conversely, local delivery of a transgene at the site of disease leads to highly localised therapeutic effects, while minimising the risk of undesirable systemic dissemination of vector and transgene. Additionally, it is possible to regulate the secretory characteristics of transgene products. ${ }^{23}$ This could lead to controlled levels of therapeutic secretory proteins systemically in lower quantities, which may be advantageous in treating SS.

\section{Delivery to salivary glands}

The anatomical configuration of major salivary glands favours localised tissue modulation by gene delivery. When a vector is introduced into major salivary glands in vivo through a cannulated duct, it can reach the luminal surface

\begin{tabular}{|c|c|c|}
\hline Vector & Advantage & Disadvantage \\
\hline Adenovirus & Highly efficient transduction & $\begin{array}{l}\text { Short term expression of the transgene } \\
\text { (weeks) }\end{array}$ \\
\hline & $\begin{array}{l}\text { Relatively simple production } \\
\text { Transduces non-dividing cells } \\
\text { Large gene packaging capacity }\end{array}$ & Potent immune response possible \\
\hline AAV & $\begin{array}{l}\text { Efficient transduction } \\
\text { Transduces non-dividing cells } \\
\text { Long term expression (months/years) } \\
\text { Modest immune response }\end{array}$ & $\begin{array}{l}\text { Limited packaging capacity (max } 4.6 \mathrm{~kb} \text { ) } \\
\text { Difficult to produce }\end{array}$ \\
\hline Non-viral & $\begin{array}{l}\text { Simple to produce } \\
\text { Low immune response } \\
\text { Inexpensive }\end{array}$ & $\begin{array}{l}\text { Low transduction efficiency } \\
\text { Relatively short term expression (days) }\end{array}$ \\
\hline
\end{tabular}




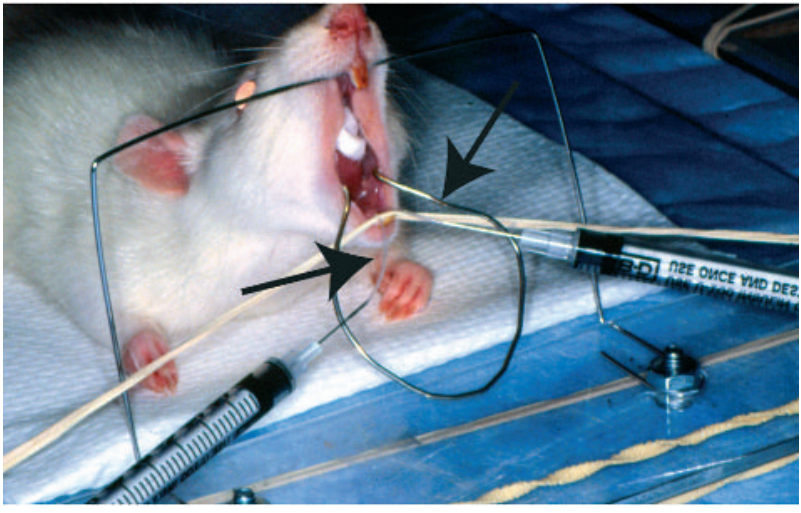

Figure 1 Ductal cannulation of submandibular glands of a rat by using custom made cannulas. A maximal volume of $50 \mu \mathrm{l}$ (mouse) or $200 \mu \mathrm{l}$ (rat) of gene transfer vector can be delivered in a retrograde fashion using $3 / 10 \mathrm{ml}$ insulin syringes connected to the cannulas. Arrows indicate the cannulas (see Baum et $a^{P^{4}}$ ). Photo courtesy of Dr L Baccaglini.

of virtually all epithelial cells (fig 1). ${ }^{24}$ Ductal cannulation of major salivary glands is a routine clinical procedure used for sialography, and clinically no anaesthesia is required. The major salivary glands are also well encapsulated, which minimises the risk of dissemination of gene transfer vectors beyond the gland. ${ }^{24}$ Many reports of successful salivary gland gene transfer have been published (for a recent review see Baum et $\left.a l^{24}\right)$. These features probably ensure effective local gene transfer, particularly useful in a disease such as SS.

\section{Safety of gene delivery}

In any medical intervention there are risks and benefits. At present, gene transfer is a developing therapeutic strategy that has resulted in significant clinical problems without any unqualified clinical success. ${ }^{26}$ None the less, gene transfer strategies are based on sound science, albeit incompletely understood at present. ${ }^{27}$ Currently, with gene transfer, the use of viral vectors presents the most risk to patients. Although viral vectors are modified to minimise their risk of replication, because our knowledge of vector biology is not complete problems can occur. For example, recombination events might take place creating replication competent viruses. As we have recently learnt from the studies in Paris using retroviral vectors to treat SCID-XI patients, unique vector integration events with severe consequences are possible. ${ }^{28}$ Also vector immune response is a major concern, and some vectors, especially adenoviral vectors, can elicit potent immune responses. ${ }^{26}$

\section{"Vector safety issue has to be solved before gene transfer is widely used in daily clinical practice"}

These potential risks must be considered in the light of patient needs and benefits. It is still highly probable that gene transfer strategies will provide opportunities for new treatments for many patients with diseases that are both fatal and associated with excess morbidity. Although most patients with SS have a normal lifespan, patients with more severe manifestations have greater morbidity, including vasculitis and lymphoma, as well as an increased risk of mortality. ${ }^{29}$ Importantly, patients with SS have considerable difficulties with chewing, swallowing, speech, Candidal infections, and other oral problems that have a deleterious impact on their quality of life. ${ }^{30}$ Current treatments for SS are inadequate. At present, we consider that localised delivery of targeted genes using rAAV serotype 2 vectors is a promising application of gene transfer for use in $S S .{ }^{21}$ rAAV vectors provide a high level of "relative safety". These vectors allow long lived transgene expression in the absence of chromosomal integration, they are naturally replication incompetent, and they elicit a minimal to modest immune response. Currently, rAAV vectors in our view are the most reasonable viral vectors to use in the treatment of a chronic autoimmune disease such as SS. Additionally, human salivary glands are well encapsulated, a circumstance that should prevent the undesirable spread of vector beyond the gland. Furthermore, the use of specific salivary cell promoters in recombinant vectors should limit transgene expression to glandular parenchyma. ${ }^{14}$ Finally, salivary glands are not vital organs, necessary for survival. If a severe adverse effect occurs a salivary gland can be removed surgically. The history of biomedical research has shown that there are risks in the development of new medical treatments. However, failure to carefully explore reasonable new treatment options for patients, in the absence of suitable conventional treatments, is not appropriate.

\section{PATHOPHYSIOLOGY AND IMMUNOLOGICAL TARGETS FOR GENE TREATMENT}

The pathogenesis of SS is not fully understood at present. Thus, there are no clearly defined molecular targets for gene transfer or conventional treatments. Although the exact pathophysiology is unknown, several possible immunological mechanisms, probably operative in the tissue destruction of salivary glands, have been identified. These may provide general targets for localised immunomodulatory gene treatment in salivary glands. Table 2 shows examples of potential candidate genes.

\section{Cytokines in relation to the microenvironment}

Immune cells produce a variety of cytokines that allow them to communicate with each other and produce an extensive, but generally self limited response. Cytokines bind to cell surface receptors present on many cell types. Epithelial cells can also produce different cytokines, and thus participate in immune events (fig 2). Also, $\mathrm{T}$ cell subsets have been categorised by the cytokines that they produce. For example, in mice, clones of $\mathrm{CD}^{+}{ }^{+} \mathrm{T}$ cells show divergence into $\mathrm{T}$ helper cell type $\mathrm{l}(\mathrm{Th} 1)$ and $\mathrm{T}$ helper cell type 2 (Th2) subpopulations. ${ }^{31}$ The Thl cells produce cytokines such as interleukin (IL)2, interferon gamma (IFN $\gamma$ ), and lymphotoxin that are associated with cell mediated immunity. ${ }^{32}$ Such activities are effective in combating viruses or intercellular organisms. ${ }^{33}$ Th2 cells produce IL4, IL5, IL6, IL10, and IL13, which stimulate humoral responses. ${ }^{34}$ In humans, the divergence of $\mathrm{CD}^{+} \mathrm{T}$ cells into Th1 and Th2 subsets is less clear. ${ }^{35} 36$

Several studies, using reverse transcription-polymerase chain reaction (RT-PCR) indicate that there is an increased level of classic Thl like cytokines-notably, IL2, IFN $\gamma$, the

Table 2 Candidate targets for gene transfer

\begin{tabular}{lll}
\hline Product & Remark & Ref \\
\hline Anti-CD20 & Depletion of B cells & 64 \\
sTNFR & Antagonise TNF $\alpha$ & 44,45 \\
IL10/vIL10 & Inhibit Th1 activity, anti-inflammatory & 21,48 \\
sCTLA-4, CD40 & Inhibit costimulation lymphocytes & 60,61 \\
Anti-BLyS & Decrease of autoreactive B cells & 63
\end{tabular}

sTNFR, soluble tumour necrosis factor receptor; vIL10, viral IL10; sCTLA4 , soluble cytotoxic lymphocyte antigen-4; anti-BLyS, anti-B lymphocyte stimulation. 


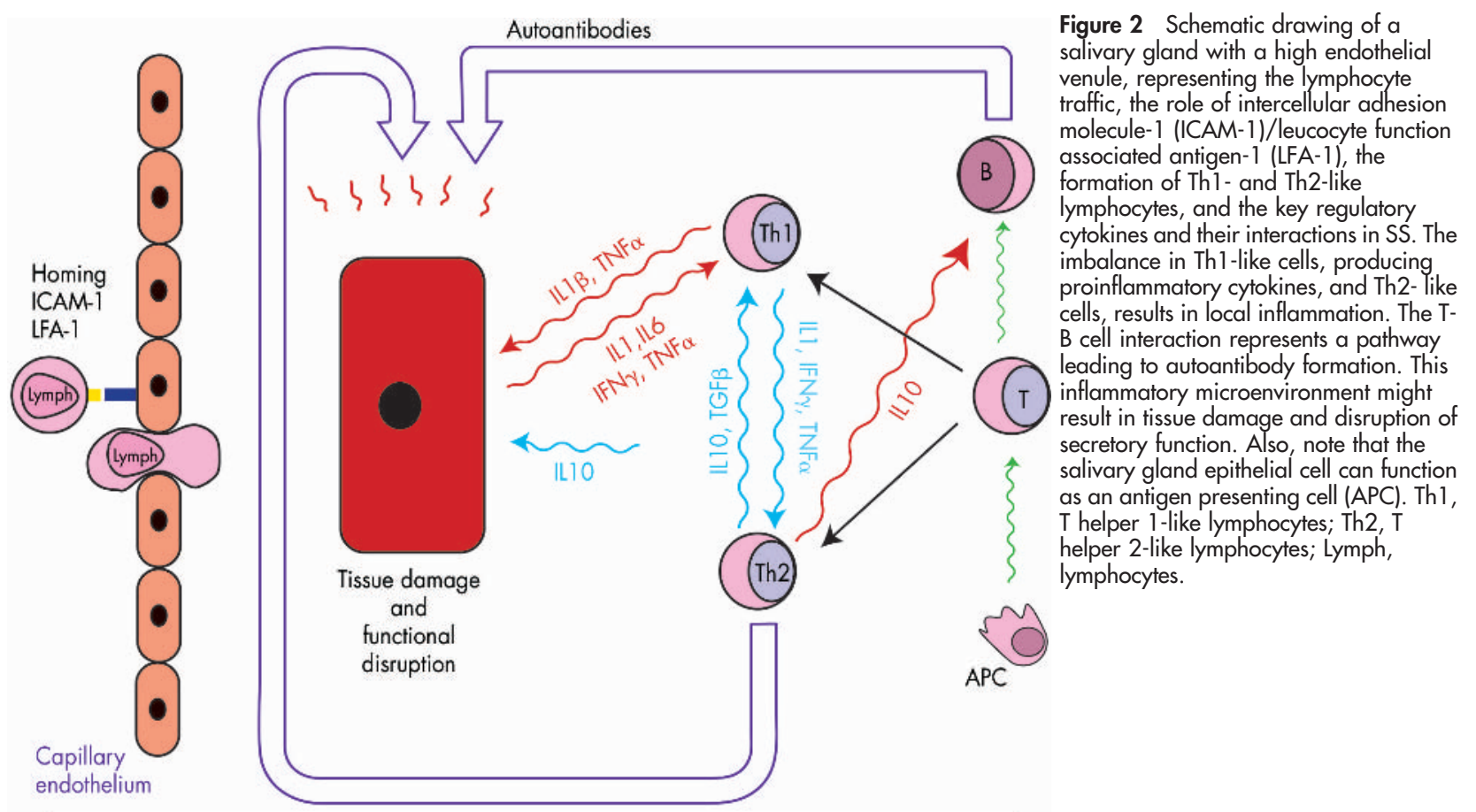

$\leadsto$ Stimulatory effect, $\leadsto$ Down regulatory effect, $\leadsto$ Antigen presentation, $\mathrm{B}^{\mathrm{B} \text { cell, }}\left(\mathrm{O}^{\mathrm{T}}\right.$ cell

proinflammatory cytokines ILl $\beta$, and TNF $\alpha$, as well as an increase in IL10, in salivary tissue of patients with SS. ${ }^{47-41}$ For example, Fox et al found that salivary gland epithelial cells produced over 40 -fold more ILl $\alpha$, IL6, and TNF $\alpha$ mRNA than epithelial cells from subjects with histologically normal salivary glands. ${ }^{39}$ Furthermore, these investigators found increased levels of IL1 $\beta$, IL6, IL10, TNF $\alpha$, and IFN $\gamma$ in the parotid saliva of patients with SS using an enzyme linked immunosorbent assay (ELISA). This suggests that the raised mRNA levels detected in minor gland tissue by RT-PCR are consistent with local cytokine protein synthesis and release. However, an important caveat to these results is that the mRNAs for all of the above cytokines, with the exception of IFN $\gamma$, have been detected in salivary tissues of healthy volunteers. $^{39}{ }^{42}$ Interestingly, Mitsias et al found a positive correlation between IFN $\gamma$ mRNA levels in cultured labial salivary glands and the intensity of the lymphocytic infiltration in the glands of patients with SS. ${ }^{43}$ None the less, it has been suggested that ILl $\alpha$ and TNF $\alpha$ have important roles as regulatory proteins inducing autoimmune related tissue damage (fig 2).$^{38}$ Indeed, patients with rheumatoid arthritis (RA) have been successfully treated by blocking TNF $\alpha$, for instance with soluble TNF $\alpha$ receptor (etanercept). ${ }^{44}$ Recently, an uncontrolled trial with an anti-TNF $\alpha$ antibody (infliximab) suggested that this was beneficial in the treatment of $\mathrm{SS}^{45}$

Although the roles of individual cytokines in the pathogenesis of SS still have not been clearly established, the proinflammatory cytokines probably stimulate cytotoxic $\mathrm{T}$ cell processes within the gland. IL10 is mainly produced by Th2 like cells, ${ }^{46}$ and IL10 is associated with a tissue protective role because it prevents an unchecked immune response to pathogens which might cause undue tissue destruction. Likewise, it has been suggested that IL10 plays a part in peripheral tolerance and in protection against autoimmunity. ${ }^{46}$ For example, IL10 can reverse the cartilage degradation induced by antigen stimulated mononuclear cells and inhibit proinflammatory cytokine production.$^{47}$ Furthermore, there is evidence suggesting that IL10 has a protective role in Fas related apoptosis. ${ }^{46}$

\section{"IL10 may be useful locally in the management of SS"}

Accordingly we have suggested that IL10 may be a general immunomodulatory factor useful locally in the management of SS. ${ }^{21}$ Currently we are using an rAAV vector, rAAV hIL10, for local delivery of the human hILl0 gene into the salivary glands..$^{218}$ This vector, when injected into ILl0 knockout mice, prevented development of endotoxic shock subsequently induced by lipopolysaccharide. ${ }^{49}$ This dramatic biological protection occurred although only modest levels of hIL10 were detectable in serum. ${ }^{49}$ The expression of hIL10 in mice after salivary gland rAAV hIL10 delivery is stable for more than eight weeks, the longest time studied and improves salivary secretion..$^{21}{ }^{48}$ Although use of this vector thus far seems promising for SS, it is tempered by remembering that IL10 can act as a potent stimulator of B cell responses. ${ }^{50} 51$ IL10 induces differentiation and activation of human B cells, which subsequently secrete larger amounts of IgA, IgG, and IgM. Therefore, treatment with IL10 theoretically could drive an increase in immunoglobulin production within infiltrated salivary glands (fig 2 ). This is of particular concern in an autoimmune disease such as SS, which is associated with an increased risk of B cell lymphoid malignancy. ${ }^{52}$

In summary, the epithelial cells in the salivary glands are active participants in the autoimmune mediated process of primary SS, as shown by their ability to express a high frequency and wide variety of cytokines. The presence of an infiltrating lymphoid focus within the gland seems to be associated with a dysregulation of normal cytokine gene expression by salivary epithelial cells. ${ }^{42}$ Local microenvironmental modulation of dysfunctional salivary epithelial cells with genes for specific cytokines, such as IL10, may result in therapeutic benefit. 


\section{Adhesion molecules and major histocompatibility complex (MHC) class II}

Adhesion molecules expressed on the surface of immune cells transduce a variety of signals and mediate important cellular interactions by binding to specific receptors expressed on target cells or by attaching to extracellular matrix components in a site-specific manner. Aberrant expression of certain adhesion molecules (mRNA and protein level) in vivo has been described in patients with autoimmune connective tissue diseases. ${ }^{53}$ For example, immunohistochemical analyses of salivary gland biopsy specimens from patients with SS show a marked expression of vascular cell adhesion molecule-1 (VCAM-1) and ICAM-1 in venules surrounded by infiltrated $\mathrm{CD} 4^{+} \mathrm{CD} 45 \mathrm{RO}^{+} \mathrm{T}$ cells. ${ }^{54}$ E-selectin was expressed on vascular endothelium with weak intensity. ${ }^{54}$ Cytokine mediated up regulation of VCAM-1 and ICAM-1, which facilitates recruitment of VLA-4 and LFA-1 expressing $\mathrm{T}$ cells, might contribute to lymphoid cell infiltration in the salivary and lachrymal glands in SS. ${ }^{54}$ Interference with this process by blocking the function of adhesion molecules may thus provide a useful therapeutic approach in SS. However, there is no conclusive evidence for tissue-specific T cell entry mediated by adhesion molecules in SS. $^{55}$

\section{T cells}

Immunohistological studies show that $75 \%$ of the cells infiltrating salivary glands in SS are T lymphocytes, mainly of the helper/inducer (CD4) subset. ${ }^{2}$ The presence of macrophages and B cells is less prominent. ${ }^{13}$ The T cells bear

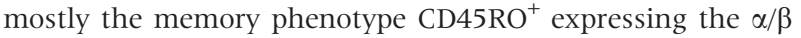
$\mathrm{T}$ cell receptor and the adhesion molecule LFA-1,1356 which promotes homing in the exocrine tissue. T cells within the gland also show an up regulation of bcl-2 and bcl- $\mathrm{x}_{\mathrm{L}}$, which would probably result in a resistance to apoptosis. ${ }^{57}{ }^{58}$ The expression of HLA-DR in the salivary and lachrymal gland epithelial cells allows the cells to present antigens to T helper cells. Correspondingly, activated $\mathrm{CD}^{+} \mathrm{T}$ cells can induce the production of proinflammatory factors by epithelial cells as well as by other lymphocytes.. ${ }^{49}$ Therapeutic strategies directed at $\mathrm{T}$ cells could include the blocking of the activated or cytotoxic T cells. This could employ, for example, soluble cytotoxic lymphocyte antigen-4 (CTLA-4), which will disrupt B7-CD28 binding, or soluble CD40, which will disrupt CD40CD40 ligand interaction, thus inhibiting the costimulation of T cells. ${ }^{60} 61$

\section{B cells}

B cells form about $20 \%$ of the infiltrating lymphocytes in the salivary glands of patients with SS, and they are responsible for the production of autoantibody immunoglobulins, such as anti-Ro and La. ${ }^{13}$ Increased levels of B lymphocyte stimulator (BLyS) have been detected in the serum of patients with SS. The level of BLyS correlates with the level of autoantibodies, suggesting that BLyS may play a part in activating autoreactive B cells. ${ }^{62}$ Also, mice transgenic for BAFF develop a disease with SS characteristics, which is manifested by severe sialadenitis, decreased saliva production, and destruction of submaxillary glands, providing a potential model for studying this aspect of the role of autoreactive B cells in SS. ${ }^{63}$ Additionally, Edwards and Cambridge described an improvement in RA after treatment with rituximab, an anti-CD20 antibody, effectively causing subtotal depletion of B cells. ${ }^{64}$ Both anti-BLyS and anti-CD20 antibody could be used as therapeutic agents in SS (table 2).

\section{M3 isoform of the muscarinic receptor}

The M3 isoform of the muscarinic receptor is an important neurotransmitter receptor involved in salivary fluid secretion. ${ }^{65-67}$ There is a reported $100 \%$ prevalence of antimuscarinic
M3 receptor antibody (M3R) in patients with primary SS, which is also detected in patients with secondary SS. ${ }^{68}$ The presence of these antibodies in secondary SS is not necessarily expected and may provide evidence for a common pathogenetic link between primary and secondary SS. These autoantibodies may contribute to sicca symptoms (that is, by blocking of M3 receptors on acinar cells, thus preventing activation of fluid secretion) and may explain associated features of autonomic dysfunction in some patients. ${ }^{68}$ Direct M3 isoform receptor autoantibody mediated tissue damage might occur through nitric oxide generation and accumulation. ${ }^{65-67}$ Muscarinic receptor stimulation with pharmacological agents improves secretory function in patients with SS. ${ }^{67}$

\section{Apoptotic processes}

Apoptotic processes could have an important role in the pathogenesis of SS. Defective apoptosis in lymphocytes could result in the accumulation of lymphoid cells in the affected tissue. Moreover, an increase in apoptosis of the exocrine gland epithelial cells might explain the loss of secretory function and the resulting exposure of intracellular autoantigens, which may evoke or enhance autoantibody production. ${ }^{69}$ The apoptotic process includes many potential therapeutic targets, including cell surface molecules such as Fas, intracellular molecules (for example, p53, Bcl-2 family members) and enzymatic pathways involving perforins and granzyme B. ${ }^{70} 71$

There are a number of conflicting reports about the level of apoptosis in the lymphocytes of patients with SS. For example, $\mathrm{T}$ cells from patients with SS show accelerated apoptosis in vitro. ${ }^{57} 58$ On the other hand, in situ DNA nick end labelling (TUNEL) studies have shown a low rate of apoptosis among infiltrating mononuclear cells. ${ }^{72}$ As noted above, increased apoptosis of ductal and acinar cells could provide an explanation for the loss of secretory function and the formation of autoantigens. However, Kong et al described an increase in Fas-Fas ligand expression in salivary glands of patients with SS, ${ }^{73}$ while Ohlsson et al found only a low level of cell death among epithelial cells in patients with secondary SS. ${ }^{72}$ Recently Mariette et al showed a colocalisation of p53 and its transcription factor p2l in salivary ductal cells surrounding lymphoid foci in the minor gland biopsy specimens from $8 / 10$ patients with SS. ${ }^{74}$ This could indicate that ductal cells have time to repair DNA damage and thus prevent apoptosis. ${ }^{74}$ Nagaraju et al reported that several generally expressed autoantigens (for example, $\alpha$-fodrin, La, and nuclear mitotic apparatus protein), and tissue restricted autoantigens (for example, M3R) targeted in SS, are specifically cleaved by granzyme $\mathrm{B}$, generating unique fragments and thus creating neoantigens. ${ }^{71}$ They argued that granzyme B cleavage of target molecules during apoptosis may be critical for autoantibody generation in SS. ${ }^{71}$

Overall, the status of apoptotic processes in the salivary glands of patients with SS is not clear; glandular hypofunction does not appear to result solely from glandular destruction through apoptosis. Moreover, normal acinar cells may be present in patients with SS with hyposalivation, ${ }^{75}$ suggesting that other immunopathological mechanisms are involved. ${ }^{76}$

Although the pathophysiological systems in SS are complex, and a precise disease mechanism is far from understood, we are employing localised gene transfer to salivary glands for two purposes: both for testing potential therapeutic efficacy and as a tool to facilitate an understanding of pathological mechanisms. With this approach it is possible to test many individual molecules, in defined models, and thus provide useful information on the possible role of these molecules in SS, even if they are not useful for treatment (table 2). 


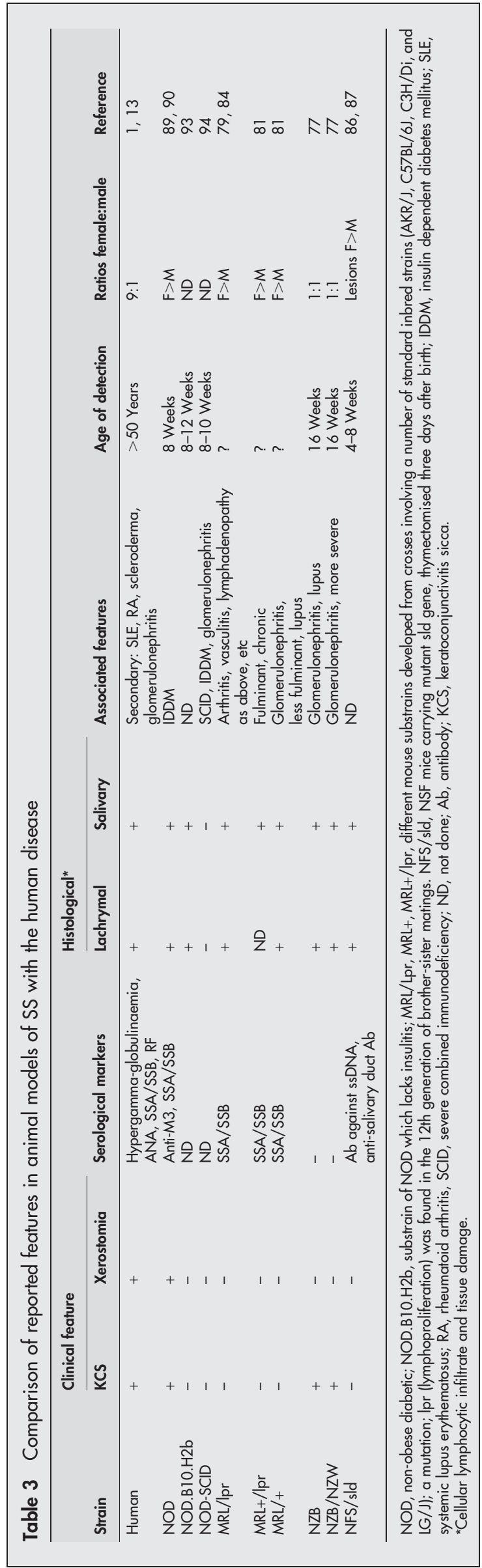

\section{ANIMAL MODELS FOR SJÖGREN'S SYNDROME}

To develop any new treatment for a disease a valid preclinical animal model is critical. The ideal animal model for SS would fulfil all of the known features of human SS, including clinical characteristics of dry eyes and dry mouth, lymphocytic cell infiltration of lachrymal and salivary glands with preferential destruction of acinar epithelium, and characteristic serological markers. Moreover, a useful animal model creates the opportunity to study early stages of the disease. A variety of animal models for SS have been used. However, none of the current models has all desired characteristics of SS. Table 3 provides a brief comparison of the most commonly used animal models of SS and their features in relation to human SS. These models are discussed in more detail below.

\section{NZB and NZB/NZW mice}

Kessler first described spontaneous histopathological changes in the NZB and NZB/NZW mouse strains, which were similar to $\mathrm{SS}^{77}$ Mononuclear cell infiltrates were noted in the lachrymal and to a lesser extent in the salivary glands. Sialochemical and modified Schirmer tests on these animals showed, however, that salivary gland pathological sequelae were present in only a small number of animals. ${ }^{78}$ Consequently, there has been little additional immunological characterisation of the exocrine tissues in these mice.

\section{MRL/Ipr mice}

Use of the MRL mouse and substrains as a model for SS has been described by Jonsson. ${ }^{79}$ Hayashi et al have also analysed local cytokine expression production in MRL/lpr mice. ${ }^{80}$ These mice exibit an overrepresentation of $\mathrm{T}$ cells bearing CD4 and $\mathrm{V}(\beta) 8$ molecules, which suggests chronic antigenic stimulation in their salivary glands. ${ }^{81}$ In addition, there is a local expression of the proinflammatory cytokine genes, IFN $\gamma$ and ILl2 (p40). This suggests that there may be a pathogenic trigger in the epithelial cells. In particular, a high level of local expression of IL12 mRNA was detected earlier in the proinflammatory stage of autoimmune lesions ${ }^{81}$ In MRL/lpr mice, overexpression of ILI $\beta$ and TNF $\alpha$ was detected before the onset of inflammatory lesions in the salivary gland, and the up regulation of IL6 mRNA was also found in the autoimmune sialadenitis occurring in MRL/lpr mice. ${ }^{82}$

$\mathrm{NZB}, \mathrm{NZB} / \mathrm{NZW}$ and MRL/lpr mice, of which there are different congenic strains, were originally bred to study autoimmunity in general, and have also been employed as models for systemic lupus erythematosus, ${ }^{83} \mathrm{RA}^{84}$ and scleroderma. ${ }^{85}$ Although they share a number of common immunological and histopathological features, all of these mice lack the critical feature of the loss of secretory function by the exocrine glands (table 3 ).

\section{NFS/sId mice}

The NFS/sld mice exhibit a sublingual gland differentiation arrest and show significant inflammatory ( $\mathrm{T}$ cell infiltrates) changes, which after neonatal thymectomy develop in both the salivary and lachrymal glands ${ }^{86}$ These $\mathrm{T}$ cell infiltrates are reactive to $\alpha$-fodrin $(120 \mathrm{kDa})$, a product of fodrin cleavage by caspase. Fodrin is a $250 \mathrm{kDa}$ membrane associated cytoskeletal protein, found in many tissues. Sera from patients with SS react positively with purified $\alpha$-fodrin (120 kDa) and recombinant human $\alpha$-fodrin protein..$^{86}$ It remains unclear whether production of antibodies against $\alpha$-fodrin is a primary event in SS, as these antibodies are also found in other autoimmune diseases. ${ }^{88}$ These mice have not been widely studied, and are not readily available or easily used. They also do not appear to exhibit salivary hypofunction. 


\section{Non-obese diabetic (NOD) mice}

With increasing age, NOD mice develop, in addition to insulin dependent diabetes mellitus, sex (female) specific histopathological changes in the salivary glands similar to those of human patients with SS. ${ }^{89}{ }^{90}$ Perhaps more importantly, they exhibit the critical clinical manifestation of declining exocrine tissue secretory function, that is, salivary hypofunction (table 3 ). Similar to findings in patients with SS, mRNA transcripts for IL1 $\beta$, IL2, IFN $\gamma$, TNF $\alpha$, IL10, as well as minimal expression of IL4, occur in NOD mice. ${ }^{91}$ Within the lymphocytic infiltrates the most intense immunohistochemical staining is for TNF $\alpha$, IL2, and IFN $\gamma .{ }^{91}$ This suggests that these cytokines may be involved in parenchymal damage, as is suspected in patients with SS.

In NOD mice, the unique expression of MHC I-A(g7) is crucial for the development of diabetes. ${ }^{92}$ Robinson et al developed a strain termed NOD.B10.H2b, which has an MHC congenic to NOD (table 3). ${ }^{93}$ These mice exhibit lymphocytic infiltrates in the exocrine tissues, typical of SS-like disease as is seen in NOD mice, but they lack the insulitis and diabetes. ${ }^{92}$ This implies that the insulitis and sialadenitis are not genetically linked in NOD mice.

Studies that have focused on the genetic profile of the NOD mouse, have suggested that both "immune" and "nonimmune" related genes are involved in the pathogenesis. The immunodeficient NOD mouse-that is, carrying the severe combined immunodeficiency (SCID) genetic profile, lacks lymphocytes almost completely. NOD-SCID mice provide the strongest evidence for the role of "non-immunogenic" genes in disease pathogenesis in this model. ${ }^{94}$ The origin of this abnormality probably resides in the salivary glands, although the mechanism is unclear. Recently, Van Blokland et al have argued that apoptosis was not a major factor in the onset of the sialadenitis (table 3 ). ${ }^{95}$

Overall, of the common animal models available, the NOD mouse seems to be the most useful for studying the pathogenesis of SS. ${ }^{89-91}$ Although not ideal, it features certain key immunological and clinical characteristics of SS.

\section{CONCLUDING REMARKS}

Immunomodulation is the first line of treatment for many autoimmune diseases. Because we do not know the exact cause of SS, the use of immunomodulatory treatments (genetic or conventional) must proceed cautiously. Ideally, immunological treatment is based on evidence that the chosen target plays a key part in the disease activity. In SS there is as yet no clear cut target for gene based or conventional treatment. Furthermore, in SS, the exocrine inflammation often occurs without prominent systemic manifestations, implying that local administration of immunomodulatory agents would be useful and possibly desirable. Although the clinical symptoms of SS can be highly debilitating, the systemic morbidity is generally mild, and mortality may not be significantly increased in patients with primary SS, except in a subset of these patients. ${ }^{96}$

As noted above, many factors, including cytokines, and MHC class II expression and adhesion molecules can serve as potential immunoregulatory targets. The production of proinflammatory cytokines by epithelial cells as well as lymphocytes is one of the most frequently described features in autoimmune diseases. Thus, effective treatment might be developed for SS by locally introducing genes encoding cytokines, which are potentially anti-inflammatory, such as IL10, or by introducing a cDNA encoding a soluble form of a key cytokine receptor, which has the ability to function as an antagonist and decrease the availability of certain cytokines, such as soluble TNF $\alpha$ receptors.

We currently think that rAAV is the preferred viral vector for immunomodulatory gene transfer in salivary glands (table 1) as it results in stable levels of transduction, and evokes a relatively low immune response. In the absence of clear targets we also propose to use gene transfer both to help elucidate the pathophysiology and to alter the course of the SS-like disease in the NOD mouse model. We are optimistic that this approach may ultimately lead to the development of new treatments for managing the exocrine pathology in patients with SS.

\section{ACKNOWLEDGEMENTS}

The authors thank Dr B Golding for his careful reading of, and comments on, the manuscript.

PP Tak is supported by the Dutch Arthritis Foundation project NR 0201-302

\section{Authors' affiliations}

M R Kok, B J Baum, S R Pillemer, Gene Therapy and Therapeutics Branch, National Institute of Dental and Craniofacial Research, National Institutes of Health, Bethesda, Maryland, USA

M R Kok, P P Tak, Division of Clinical Immunology and Rheumatology, Academic Medical Centre/University of Amsterdam, Amsterdam, The Netherlands

\section{REFERENCES}

1 Bloch BW, Wohl MJ, Bunim JJ. Sjögren's syndrome. A clinical, pathological and serological study of sixty-two cases. Medicine (Baltimore) 1965;44:187-231.

2 Adamson TCd, Fox RI, Frisman DM, Howell FV. Immunohistologic analysis of lymphoid infiltrates in primary Sjögren's syndrome using monoclonal antibodies. J Immunol 1983; 130:203-8.

3 Pillemer SR, Matteson EL, Jacobsson LT, Martens PB, Melton $\sqcup$ 3rd, O'Fallon WM, et al. Incidence of physician-diagnosed primary Siögren syndrome in residents of Olmsted County, Minnesota. Mayo Clin Proc 2001;76:593-9.

4 Fox PC, Brennan M, Di Sun P. Cytokine expression in human labial minor salivary gland epithelial cells in health and disease. Arch Oral Biol 1999:44(suppl 1):S49-52.

5 Fox PC, van der Ven PF, Baum BJ, Mandel ID. Pilocarpine for the treatment of xerostomia associated with salivary gland dysfunction. Oral Surg Oral Med Oral Pathol 1986;61:243-8.

6 Kruize AA, Hene RJ, Kallenberg CG, van Bijsterveld OP, van der Heide A, Kater $\mathrm{L}$, et al. Hydroxychloroquine treatment for primary Siögren's syndrome: a two year double blind crossover trial. Ann Rheum Dis 1993;52:360-4.

7 Fox PC, Datiles M, Atkinson JC, Macynski AA, Scott J, Fletcher D, et al. Prednisone and piroxicam for treatment of primary Siögren's syndrome. Clin Exp Rheumatol 1993;11:149-56.

8 Evans $\mathrm{CH}$, Ghivizzani SC, Kang R, Muzzonigro T, Wasko MC, Herndon JH, et al. Gene therapy for rheumatic diseases. Arthritis Rheum 1999;42:1-16.

9 Baum BJ, O'Connell BC. In vivo gene transfer to salivary glands. Crit Rev Oral Biol Med 1999; 10:276-83.

10 Vervoordeldonk MJ, Tak PP. Gene therapy in rheumatic diseases. Best Pract Res Clin Rheumatol 2001;15:771-88.

11 Kay MA, Glorioso JC, Naldini L. Viral vectors for gene therapy: the art of turning infectious agents into vehicles of therapeutics. Nat Med 2001;7:33-40.

12 Fox RI, Michelson P, Casiano CA, Hayashi J, Stern M. Sjögren's syndrome. Clin Dermatol 2000;18:589-600.

13 Jonsson R, Haga H-J, Gordon TP. Sjögren's syndrome. In: Koopman WJ, ed. Arthritis and allied conditions: a textbook of rheumatology, 14th ed. Philadelphia: Lippincott Williams \& Wilkins, 2001:1736-59.

14 Zheng C, Hoque AT, Braddon VR, Baum BJ, O'Connell BC. Evaluation of salivary gland acinar and ductal cell-specific promoters in vivo with recombinant adenoviral vectors. Hum Gene Ther 2001;12:2215-23.

15 Kagami H, Atkinson JC, Michalek SM, Handelman B, Yu S, Baum BJ, et al. Repetitive adenovirus administration to the parotid gland: role of immunological barriers and induction of oral tolerance. Hum Gene Ther 1998;9:305-13.

16 Nishikawa M, Huang L. Nonviral vectors in the new millennium: delivery barriers in gene transfer. Hum Gene Ther 2001;12:861-70.

17 Shai E, Falk H, Honigman A, Panet A, Palmon A. Gene transfer mediated by different viral vectors following direct cannulation of mouse submandibular salivary glands. Eur J Oral Sci 2002;110:254-60.

18 Morgan RA, Anderson WF. Human gene therapy. Annu Rev Biochem 1993:62:191-217.

19 Schnell MA, Zhang Y, Tazelaar J, Gao GP, Yu QC, Qian R, et al. Activation of innate immunity in nonhuman primates following intraportal administration of adenoviral vectors. Mol Ther 2001;3(5 Pt 1):708-22.

20 Zhao N, Liu DP, Liang CC. Hot topics in adeno-associated virus as a gene transfer vector. Mol Biotechnol 2001;19:229-37.

21 Yamano S, Huang LY, Ding C, Chiorini JA, Goldsmith CM, Wellner RB, et al. Recombinant adeno-associated virus serotype 2 vectors mediate stable interleukin 10 secretion from salivary glands into the bloodstream. Hum Gene Ther 2002;13:287-98. 
22 Braddon VR, Chiorini JA, Wang S, Kotin RM, Baum BJ. Adenoassociated virus-mediated transfer of a functional water channel into salivary epithelial cells in vitro and in vivo. Hum Gene Ther 1998;9:2777-85.

23 Hoque AT, Baccaglini L, Baum BJ. Hydroxychloroquine enhances the endocrine secretion of adenovirus-directed growth hormone from rat submandibular glands in vivo. Hum Gene Ther 2001;12:1333-41.

24 Baum BJ, Wellner R, Zheng C. Gene transfer to salivary glands. Int Rev Cytol 2001;213:93-146.

25 Mastrangeli A, O'Connell B, Aladib W, Fox PC, Baum BJ, Crystal RG. Direct in vivo adenovirus-mediated gene transfer to salivary glands. Am J Physiol 1994;266(6 Pt 1):G1146-55.

26 Marshall E. Gene therapy: viral vectors still pack surprises. Science 2001;294: 1640 .

27 Leiden JM. Gene therapy-promise, pitfalls, and prognosis. N Engl J Med 1995;333:871-3.

28 Hacein-Bey-Abina S, von Kalle C, Schmidt M, Le Deist F, Wulffraat N, Mclntyre $E$, et al. A serious adverse event after successful gene therapy for $X$ linked severe combined immunodeficiency. N Engl J Med 2003;348:255-6.

29 loannidis JP, Vassiliou VA, Moutsopoulos HM. Long-term risk of mortality and lymphoproliferative disease and predictive classification of primary Siögren's syndrome. Arthritis Rheum 2002;46:741-7.

30 Strombeck B, Ekdahl C, Manthorpe R, Wikstrom I, Jacobsson L. Health-related quality of life in primary Sjögren's syndrome, rheumatoid arthritis and fibromyalgia compared to normal population data using SF-36. Scand J Rheumatol 2000;29:20-8.

31 Mosmann TR, Cherwinski H, Bond MW, Giedlin MA, Coffman RL. Two types of murine helper T cell clone. I.Definition according to profiles of lymphokine activities and secreted proteins. J Immunol 1986;136:2348-57.

32 Abbas AK, Murphy KM, Sher A. Functional diversity of helper T lymphocytes. Nature 1996;383:787-93

33 Salgame P, Abrams JS, Clayberger C, Goldstein H, Convit J, Modlin RL, et al. Differing lymphokine profiles of functional subsets of human CD4 and CD8 T cell clones. Science 1991;254:279-82.

34 Mosmann TR, Coffman RL. TH1 and TH2 cells: different patterns of lymphokine secretion lead to different functional properties. Annu Rev Immunol 1989:7:145-73.

35 Umetsu DT, Jabara HH, DeKruyff RH, Abbas AK, Abrams JS, Geha RS Functional heterogeneity among human inducer T cell clones. J Immunol 1988; 140:4211-16.

36 Zumla A, Mathur M, Stewart J, Wilkinson L, Isenberg D. T cell receptor expression in Siögren's syndrome. Ann Rheum Dis 1991;50:691-3.

37 Ferraccioli GF, De Vita S. Cytokine expression in the salivary glands of Sjögren's syndrome patients in relation to tissue infiltration and lymphoepithelial lesions. Arthritis Rheum 1997:40:987-90.

38 Fox RI, Kang HI, Ando D, Abrams J, Pisa E. Cytokine mRNA expression in salivary gland biopsies of Sjögren's syndrome. J Immunol 1994; 152:5532-9

39 Fox PC, Grisius MM, Bermudez DK, Sun D. Cytokine mRNA expression in labial salivary glands and cytokine secretion in parotid saliva in Siögren's syndrome. Adv Exp Med Biol 1998;438:909-15

40 Ohyama Y, Nakamura S, Matsuzaki G, Shinohara M, Hiroki A, Fujimura T et al. Cytokine messenger RNA expression in the labial salivary glands of patients with Siögren's syndrome. Arthritis Rheum 1996:39:1376-84.

41 Moutsopoulos HM. Sjögren's syndrome: autoimmune epithelitis. Clin Immunol Immunopathol 1994;72:162-5.

42 Sun D, Emmert-Buck MR, Fox PC. Differential cytokine mRNA expression in human labial minor salivary glands in primary Sjögren's syndrome. Autoimmunity 1998;28:125-37.

43 Mitsias DI, Tzioufas AG, Veiopoulou C, Zintzaras E, Tassios IK, Kogopoulou $O$, et al. The Th1/Th2 cytokine balance changes with the progress of the immunopathological lesion of Siögren's syndrome. Clin Exp Immunol 2002;128:562-8.

44 Bathon JM, Martin RW, Fleischmann RM, Tesser JR, Schiff MH, Keystone EC, et al. A comparison of etanercept and methotrexate in patients with early rheumatoid arthritis. N Engl J Med 2000;343:1586-93.

45 Steinfeld SD, Demols P, Salmon I, Kiss R, Appelboom T. Infliximab in patients with primary Siögren's syndrome: a pilot study. Arthritis Rheum 2001;44:2371-5.

46 Moore KW, de Waal Malefyt R, Coffman RL, O'Garra A. Interleukin-10 and the interleukin-10 receptor. Annu Rev Immunol 2001;19:683-765.

47 van Roon JA, van Roy JL, Gmelig-Meyling FH, Lafeber FP, Bijlsma JW. Prevention and reversal of cartilage degradation in rheumatoid arthritis by interleukin-10 and interleukin-4. Arthritis Rheum 1996:39:829-35.

48 Yamano S, Kok M, Tsutsui M, Tak P, Pillemer S, Baum B. Local IL-10 gene transfer with an adeno-associated virus in a murine model of Siögren's syndrome enhances salivary flow. Molecular Therapy 2002;5(suppl):s4-5.

49 Yamano S, Scott DE, Huang LY, Mikolajczyk M, Pillemer SR, Chiorini JA, et al. Protection from experimental endotoxemia by a recombinant adenoassociated virus encoding interleukin 10. J Gene Med 2001;3:450-7.

50 Cortes J, Kurzrock R. Interleukin-10 in non-Hodgkin's lymphoma. Leuk Lymphoma 1997:26:251-9.

51 Go NF, Castle BE, Barrett R, Kastelein R, Dang W, Mosmann TR, et al. Interleukin 10, a novel $B$ cell stimulatory factor: unresponsiveness of $X$ chromosome-linked immunodeficiency B cells. J Exp Med 1990:172:1625-31.

52 Shin SS, Sheibani K, Fishleder A, Ben-Ezra J, Bailey A, $\mathrm{Koo} \mathrm{CH}$, et al. Monocytoid B-cell lymphoma in patients with Sjögren's syndrome: a clinicopathologic study of 13 patients. Hum Pathol 1991;22:422-30

53 Sfikakis PP, Mavrikakis M. Adhesion and lymphocyte costimulatory molecules in systemic rheumatic diseases. Clin Rheumatol 1999;18:317-27.
54 Saito I, Terauchi K, Shimuta M, Nishiimura S, Yoshino K, Takeuchi T, et al. Expression of cell adhesion molecules in the salivary and lacrimal glands of Siögren's syndrome. J Clin Lab Anal 1993;7:180-7.

55 Westermann J, Engelhardt B, Hoffmann JC. Migration of T cells in vivo: molecular mechanisms and clinical implications. Ann Intern Med 2001;135:279-95

56 Skopouli FN, Fox PC, Galanopoulou V, Atkinson JC, Jaffe ES, Moutsopoulos HM. T cell subpopulations in the labial minor salivary gland histopathologic lesion of Siögren's syndrome. J Rheumatol 1991;18:210-14.

57 Kong L, Ogawa N, McGuff HS, Nakabayashi T, Sakata KM, Masago R, et al. $\mathrm{Bcl}-2$ family expression in salivary glands from patients with primary Siögren's syndrome: involvement of Bax in salivary gland destruction. Clin Immunol Immunopathol 1998:88:133-41.

58 Ogawa N, Dang H, Kong L, Anaya JM, Liu GT, Talal N. Lymphocyłe apoptosis and apoptosis-associated gene expression in Siögren's syndrome. Arthritis Rheum 1996;39:1875-85.

59 Oxholm P, Daniels TE, Bendtzen K. Cytokine expression in labial salivary glands from patients with primary Sjögren's syndrome. Autoimmunity 1992:12:185-91.

60 Linsley PS, Wallace PM, Johnson J, Gibson MG, Greene JL, Ledbetter JA, ef al. Immunosuppression in vivo by a soluble form of the CTLA-4 T cell activation molecule. Science 1992;257:792-5.

61 Datta SK, Kalled SL. CD40-CD40 ligand interaction in autoimmune disease. Arthritis Rheum 1997;40:1735-45.

62 Mariette X, Roux S, Zhang J, Bengoufa D, Lavie F, Zhou T, et al. The level of BLyS (BAFF) correlates with the titre of autoantibodies in human Sjögren's syndrome. Ann Rheum Dis 2003:62:168-71.

63 Groom J, Kalled SL, Cutler AH, Olson C, Woodcock SA, Schneider P, et al. Association of BAFF/BLyS overexpression and altered B cell differentiation with Siögren's syndrome. J Clin Invest 2002;109:59-68.

64 Edwards JC, Cambridge G. Sustained improvement in rheumatoid arthritis following a protocol designed to deplete $\mathrm{B}$ lymphocytes. Rheumatology (Oxford) 2001;40:205-11.

65 Bacman S, Sterin-Borda L, Camusso JJ, Arana R, Hubscher O, Borda E. Circulating antibodies against rat parotid gland $M 3$ muscarinic receptors in primary Sjögren's syndrome. Clin Exp Immunol 1996;104:454-9.

66 Bacman S, Perez Leiros C, Sterin-Borda L, Hubscher O, Arana R, Borda E. Autoantibodies against lacrimal gland $M 3$ muscarinic acetylcholine receptors in patients with primary Sjögren's syndrome. Invest Ophthalmol Vis Sci 1998; 39:151-6.

67 Fox RI, Konttinen Y, Fisher A. Use of muscarinic agonists in the treatment of Sjögren's syndrome. Clin Immunol 2001;101:249-63.

68 Waterman SA, Gordon TP, Rischmueller M. Inhibitory effects of muscarinic receptor autoantibodies on parasympathetic neurotransmission in Siögren's syndrome. Arthritis Rheum 2000:43:1647-54

69 Itoh N, Yonehara S, Ishii A, Yonehara M, Mizushima S, Sameshima M, et al. The polypeptide encoded by the cDNA for human cell surface antigen Fas can mediate apoptosis. Cell 1991;66:233-43.

70 Patel YI, McHugh NJ. Apoptosis-new clues to the pathogenesis of Sjögren's syndrome? Rheumatology (Oxford) 2000;39:119-21.

71 Nagaraju K, Cox A, Casciola-Rosen L, Rosen A. Novel fragments of the Siögren's syndrome autoantigens alpha-fodrin and type 3 muscarinic acetylcholine receptor generated during cytotoxic lymphocyte granuleinduced cell death. Arthritis Rheum 2001:44:2376-86.

72 Ohlsson M, Skarstein K, Bolstad Al, Johannessen AC, Jonsson R. Fas-induced apoptosis is a rare event in Sjögren's syndrome. Lab Invest 2001;81:95-105.

73 Kong L, Ogawa N, Nakabayashi T, Liu GT, D'Souza E, McGuff HS, et al. Fas and Fas ligand expression in the salivary glands of patients with primary Siögren's syndrome. Arthritis Rheum 1997:40:87-97.

74 Mariette X, Sibilia J, Roux S, Meignin V, Janin A. A new defensive mechanism to prevent apoptosis in salivary ductal cells from patients with Siögren's syndrome: over-expression of p53 and p21. Rheumatology (Oxford) 2002:41:96-9.

75 Humphreys-Beher MG, Brayer J, Yamachika S, Peck AB, Jonsson R. An alternative perspective to the immune response in autoimmune exocrinopathy: induction of functional quiescence rather than destructive autoaggression. Scand J Immunol 1999:49:7-10.

76 Pedersen AM, Dissing S, Fahrenkrug J, Hannibal J, Reibel J, Nauntofte B. Innervation pattern and $\mathrm{Ca} 2+$ signalling in labial salivary glands of healthy individuals and patients with primary Sjögren's syndrome (pSS). J Oral Pathol Med 2000;29:97-109.

77 Kessler HS. A laboratory model for Siögren's syndrome. Am J Pathol 1968:52:671-85.

78 Wolff A, Scott J, Woods K, Fox PC. An investigation of parotid gland function and histopathology in autoimmune disease-prone mice of different age groups. J Oral Pathol Med 1991;20:486-9.

79 Jonsson R, Tarkowski A, Backman K, Holmdahl R, Klareskog L. Sialadenitis in the MRL-I mouse: morphological and immunohistochemical characterization of resident and infiltrating cells. Immunology 1987;60:611-16.

80 Hayashi Y, Haneji N, Hamano H, Yanagi K, Takahashi M, Ishimaru N. Effector mechanism of experimental autoimmune sialadenitis in the mouse model for primary Sjögren's syndrome. Cell Immunol 1996;171:217-25.

81 Hayashi Y, Haneji N, Hamano H. Pathogenesis of Sjögren's syndrome-like autoimmune lesions in MRL/lpr mice. Pathol Int 1994;44:559-68.

82 Hamano H, Saito I, Haneji N, Mitsuhashi Y, Miyasaka N, Hayashi Y. Expressions of cytokine genes during development of autoimmune sialadenitis in MRL/lpr mice. Eur J Immunol 1993;23:2387-91.

83 Furukawa F. Animal models of cutaneous lupus erythematosus and lupus erythematosus photosensitivity. Lupus 1997;6:193-202.

84 Koopman WJ, Gay S. The MRL-lpr/lpr mouse. A model for the study of rheumatoid arthritis. Scand J Rheumatol Suppl 1988;75:284-9. 
85 Le Hir M, Martin M, Haas C. A syndrome resembling human systemic sclerosis (scleroderma) in MRL/lpr mice lacking interferon-gamma (IFN-gamma) receptor (MRL/IprgammaR-/-). Clin Exp Immunol 1999;1 15:281-7.

86 Haneji N, Hamano H, Yanagi K, Hayashi Y. A new animal model for primary Sï̈gren's syndrome in NFS/sld mutant mice. J Immunol 1994;153: 2769-77.

87 Haneji N, Nakamura T, Takio K, Yanagi K, Higashiyama H, Saito I, et al. Identification of alpha-fodrin as a candidate autoantigen in primary Sjögren's syndrome. Science 1997;276:604-7.

88 Witte T, Matthias T, Arnett FC, Peter HH, Hartung K, Sachse C, et al. IgA and lgG autoantibodies against alpha-fodrin as markers for Sjögren's syndrome. Systemic lupus erythematosus. J Rheumatol 2000;27:2617-20.

89 Humphreys-Beher MG, Hu Y, Nakagawa Y, Wang PL, Purushotham KR. Utilization of the non-obese diabetic (NOD) mouse as an animal model for the study of secondary Siögren's syndrome. Adv Exp Med Biol 1994;350:631-6.

90 Makino S, Kunimoto K, Muraoka Y, Mizushima Y, Katagiri K, Tochino Y. Breeding of a non-obese, diabetic strain of mice. Jikken Dobutsu 1980;29:1-13

91 Yamano S, Atkinson JC, Baum BJ, Fox PC. Salivary gland cytokine expression in NOD and normal BALB/c mice. Clin Immunol 1999;92:265-75.
92 Lund T, O'Reilly L, Hutchings P, Kanagawa O Simpson E, Gravely R, et al. Prevention of insulin-dependent diabetes mellitus in non-obese diabetic mice by transgenes encoding modified I-A beta-chain or normal I-E alpha-chain. Nature 1990:345:727-9.

93 Robinson CP Yamachika S, Bounous DI, Brayer J, Jonsson R, Holmdahl R, et al. A novel NOD-derived murine model of primary Sjögren's syndrome. Arthritis Rheum 1998;41:150-6.

94 Robinson CP, Yamamoto H, Peck AB, Humphreys-Beher MG. Genetically programmed development of salivary gland abnormalities in the NOD (nonobese diabetic)-scid mouse in the absence of detectable lymphocytic infiltration: a potential trigger for sialoadenitis of NOD mice. Clin Immunol Immunopathol 1996;79:50-9.

95 Van Blokland SC, Van Helden-Meeuwsen CG, Wierenga-Wolf AF, Tielemans D, Drexhage HA, Van De Merwe JP, et al. Apoptosis and apoptosis-related molecules in the submandibular gland of the nonobese diabetic mouse model for Sjögren's syndrome: limited role for apoptosis in the development of sialoadenitis. Lab Invest 2003;83:3-11.

96 Martens PB, Pillemer SR, Jacobsson LT, O'Fallon WM, Matteson EL. Survivorship in a population based cohort of patients with Sjögren's syndrome, 1976-1992. J Rheumatol 1999;26:1296-300.

\section{Get published within days of acceptance with ARD}

We are delighted to announce that the Annals of the Rheumatic Diseases is launching a "publish ahead of print" programme from February 2004. Selected papers will be fast tracked and published online months before they appear in the print journal.

Papers of major significance to the international rheumatology community will be published within days of acceptance. The published article will be the raw accepted manuscript; edited and typeset versions will also be published as soon as they are available.

In addition to being available on ARD Online, the publish ahead of print articles will be searchable through PubMed/Medline-establishing primacy for your work. They will be linked from the ARD Online home page.

$A R D^{\prime}$ s publish ahead of print programme is unique among the major rheumatology journals - to take advantage of this service submit your papers to Annals of the Rheumatic Diseases using our online submission and review system Bench>Press (http:// submit-ard.bmijournals.com). For further information contact ARD@bmigroup.com. 